\title{
Utholdenhetstrening og risiko for atrieflimmer
}

\section{Deltagelse i Birkebeinerrennet og langvarig utholdenhetstrening ser ut til å øke risikoen for atrieflimmer.}

Mange er aktive på et høyere nivå enn det som har dokumentert gunstige effekter på helsen. Målet med mitt doktorgradsarbeid var å kartlegge sammenhengen mellom deltagelse i Birkebeinerrennet, langvarig regelmessig utholdenhetstrening og risiko for atrieflimmer.

Vi undersøkte forekomsten av atrieflimmer blant 509 eldre mannlige deltagere i Birkebeinerrennet og sammenlignet med et utvalg fra den generelle befolkningen. Etter justering for alder og kjente risikofaktorer for atrieflimmer var deltagelse i Birkebeinerrennet forbundet med 6 prosentpoeng $ø \mathrm{kt}$ risiko for atrieflimmer. I en annen studie undersøkte vi sammenhengen mellom regelmessig utholdenhetstrening og risiko for atrieflimmer blant 3545 menn over 52 år, omtrent halvparten var tidligere eller fortsatt aktive deltagere i Birkebeinerrennet. Justert risiko for atrieflimmer økte med $16 \%$ per tiår med trening og var høyest blant dem som hadde trent regelmessig i minst 30 år. Også blant de 1449 kvinnene som deltok i studien, så trening ut til å være forbundet med økt risiko for atrieflimmer. Studien er den første til å vise denne sammenhengen blant kvinner.

Resultatene gir ikke grunn til å fraråde trening eller deltagelse i Birkebeinerrennet, men eldre skiløpere og andre aktive bør være oppmerksomme på symptomer på atrieflimmer, og leger bør være på utkikk etter arytmi hos pasienter som har trent gjennom mange år.

\section{Marius Myrstad}

m-myrsta@online.no

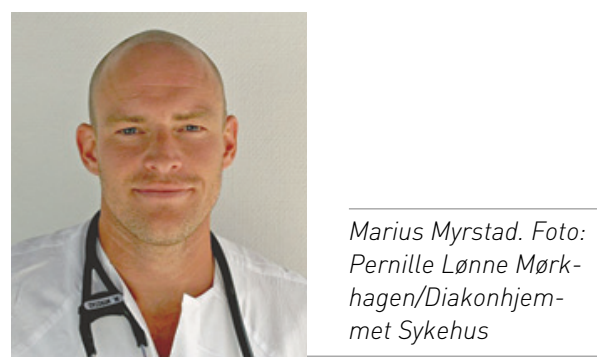

Disputas

Marius Myrstad disputerte for ph.d.-graden ved Universitetet i Oslo 15.10. 2015. Tittelen på avhandlingen er Endurance exercise and atrial fibrillation. Atrial fibrillation among Norwegian veteran endurance athletes and the association between endurance exercise and risk of atrial fibrillation.

\section{Populasjonsbasert kartlegging av idiopatisk inflammatorisk myopati}

\section{Myosittpasienter har hyppig forekomst av autoantistoffer, lunge- og spiserørsaffeksjon samt økt dødelighet og kreftrisiko.}

De idiopatiske inflammatoriske myopatiene er alvorlige, systemiske bindevevssykdommer av ukjent årsak. De karakteriseres av progressivt tap av tverrstripet muskulatur. Kunnskap om og kartlegging av disse sykdommene er begrenset på verdensbasis, og i Norge foreligger det ingen tidligere studier.

I dette doktorgradsarbeidet har vi utført en omfattende datainnsamling fra alle avdelinger og sykehus i Helse Sør-Øst fra 2003 til 2012. Studien inkluderer halve Norges befolkning, 2,6 millioner, og gir detaljert oversikt over kliniske kjennetegn, laboratorieprøver, røntgenfunn, kreftforekomst og dødelighet blant pasienter med de tre hovedtypene av idiopatiske inflammatoriske myopatier, nemlig dermatomyositt, polymyositt og inklusjonslegememyositt.

Vi fant at en punktprevalens i 2012 for dermatomyositt og polymyositt var 8,7/100 000 . Tilsvarende tall for inklusjonslegememyositt var 3,5/100 000. Tallene var høyere enn tidligere antatt, særlig for inklusjonslegememyositt. Vi fant videre høy affeksjon av ekstramuskulære organer og autoantistoffer og mortalitet på $27 \%$. Frekvensen av sykdomsrelaterte dødsfall var på $64 \%$ og kreftrisikoen blant pasienter med dermatomyositt var doblet.

Funnene i denne avhandlingen gir unik og oppdatert kunnskap om myositter og bekrefter og forsterker inntrykket av at dette er sykdommer som medfører høy mortalitet og morbiditet, til tross for nye behandlingsmuligheter. Funnene underbygger også hvor viktig det er med kreftscreening blant pasienter med dermatomyositt og styrker synspunktet om at pasienter med myositt bør få jevnlig kartlegging av lunge-, hjerte- og spiserørsaffeksjon.

\section{Gerd Cecilie Dobloug}

gcdobloug@doctors.org.uk

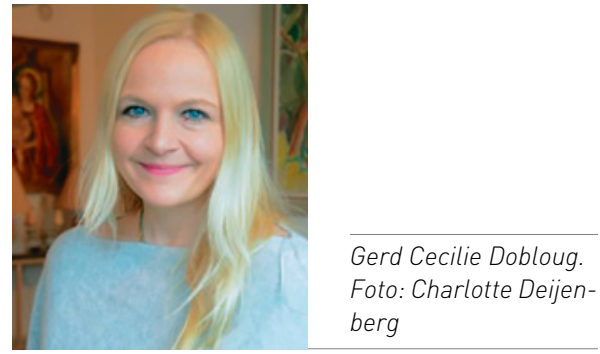

\section{Disputas}

Gerd Cecilie Dobloug disputerte for ph.d.graden ved Universitet i Oslo 29.5. 2015. Tittelen på avhandlingen er: Clinical epidemiology of the idiopathic inflammatory myopathies. A population-based study from South-east Norway. 